\title{
SEXUAL HARASSMENT AT WORKPLACE: AN EXPLORATORY STUDY AT
} BELAGAVI

\section{Dr. Vishalakshi Honnakatti}

\author{
Assistant Professor And Head Of The Department. Department Of \\ Psychology. Govt First Grade College \& P. G. Studies Center For Women. \\ Bailhongal: 591102
}

ABSTRACT Today's world is full of with the term molestation and Sexual Harassment. Sexual Harassment can be identified as a behavior. It will normally terms be outlined as AN unwelcome behavior of sexual nature. Sexual harassment at geographic point may be a universal downside within the world whether or not it's a developed nation or a developing nation or AN underdeveloped nation, atrocities and cruelties against women is common everywhere. It is a retardant giving negative result on each men and girls. It is seen to be happening additional with ladies gender as they're thought of to be the foremost vulnerable section of the society currently. Sexual harassment so may be a major problem within the geographic point and it's become one in every of those problems that receive heaps of negative attention. This Research is done by exploratory type, and utilized Primary and secondary sources that are essential and vital for data analysis. The secondary sources are collected from on the Internet, articles, other research journals, books and exposed acts in light of the subject. The primary data were collected through Interview schedules of different professional. The Research utilized rates for significant investigation of the outcomes. At the point when men and Women work they are viewed as the change operators for the general public as the ladies are given more significance. The most extreme sexual harassment issue happens to women than men. And the safeguards/protection under the POSH Act is available only to women.

\section{KEYWORDS : Sexual Harassment, Workplace, Harassment And Gender Difference.}

\section{INTRODUCTION:}

Workplace Harassment is a section that's gaining visibility thanks to the impact it's on overall structure culture yet as worker well-being. It is the only most vital reason for workrelated stress. Many people use geographic point harassment and molestation interchangeably, or believe it to be the foremost harmful. However, they are not the same. Sexual harassment may be a set, or one in every of the kinds, of workplace harassment. Also, bullying, belittling or shaming, aggression, discrimination, and abuse at the global point additionally qualifies as harassment and is equally harmful. At a geographic point, harassment is prohibited on the following grounds of discrimination - race, colour, religion, national origin, ancestry, place of origin, age, physical disability, mental disability, marital status, and/or sexual orientation. As per the definition shared by the Supreme Court, 'Sexual Harassment' includes unwelcome sexually tinted behaviour, whether directly or by implication, such as physical contact and advances, demands for sexual

favours, sexually colored remarks, showing pornography, or any other unwelcome physical, and verbal or non-verbal conduct of a sexual nature.

Some common real-life comments created at Indian workplaces: "You You are so tall, are you sure you need those heels? " "Walk slowly, I can feel the ground shaking when you are around." (Comments received by a fat person.) "Rani can afford to buy that expensive car as her income is her pocket money, whereas I am the sole breadwinner, and that is why I deserve the promotion more than her." "Hey Pakistani, how are you doing today? " (Boss addressing AN Indian Muslim junior team member.) "Let's look at promoting that Reddy guy first, that Tamil guy can wait." (Preferential treatment based on origin or community.) "We men will cite cup-sizes, so why can't you women talk about car brands?"..

So it is very necessary to find answers and understand the harassment is sexual harassment or workplace-related harassment? And Can both men and women be victims of workplace sexual harassment?

What is sexual harassment: Sexual harassment includes "any one or more" of the following "unwelcome acts or behaviour" committed directly or by implication: Physical contact and advances, A demand or request for sexual favours, Sexually colored remarks, Showing porno or the other unwelcome physical, verbal or non-verbal conduct of sexual nature.

\section{WHAT IS A WORKPLACE?}

A workplace is defined as "any place visited by the employee arising out of or during the course of employment, including transportation provided by the employer for undertaking such a journey." As per this definition, a workplace covers both the organised and un-organised sectors.

It also includes all workplaces whether owned by Indian or foreign company having a place of work in India. As per the Act, workplace includes:

- Government organizations, as well as Government company, corporations and cooperative societies;

- non-public sector organisations, venture, society, trust, organisation or service suppliers etc.

- providing services that are business, vocational, instructional, sports, professional, entertainment, indu strial,

- health connected or money activities, as well as production, supply, sale, distribution or service;

- Hospitals/Nursing Homes;

- Sports Institutes/Facilities;

- Places visited by the worker (including whereas on travel) as well as transportation provided by employer;

- Adwelling place or house.

Below are samples of behaviour which will or might not represent workplace sexual harassment in isolation. At the same time, it is important to remember that more often than not, such behaviour occurs in cluster. Distinguishing between these different possibilities is not an easy task and requires essential training and skill building. Some samples of behaviour that represent sexual harassment at the workplace:

1. Making sexually suggestive remarks or innuendos.

2. Serious or perennial offensive remarks, such as teasing related to a person's body or appearance.

3. Offensive comments or jokes.

4. Inappropriate queries, suggestions or remarks about a 
person's sex life.

5. Displaying sexist or different offensive photos, posters, mms, sms, whatsapp, or e-mails.

6. Intimidation, threats, blackmail around sexual favours.

7. Threats, intimidation or revenge against associate worker World Health Organization speaks up concerning unwelcome behaviour with sexual overtones.

8. Unwelcome social invites, with sexual overtones commonly understood as flirting.

9. Unwelcome sexual advances which can or might not be among guarantees or threats, explicit or implicit. 10. Physical contact such as touching or pinching.

11. Caressing, petting or smooching somebody against her can (could be thought-about assault).

12. Invasion of private house (getting too shut for no reason, brushing against or cornering someone).

13. Persistently asking somebody out, despite being turned down.

14. Stalking an individual.

15. Abuse of authority or power to threaten a person's job or undermine her performance against sexual favors.

16. incorrectly inculpative and undermining an individual behind closed doors for sexual favors.

17. Controlling a person's reputation by rumor-mongering about her private life.

SOME SAMPLES OF BEHAVIOR WHICH WILL INDICATE UNDERLYING SEXUAL HARASSMENT AT THE WORKPLACE AND B INDICATE INQUIRY:

1. Criticizing, insulting, blaming, reprimanding or condemning an employee in public.

2. Exclusion from cluster activities or assignments while not a sound reason.

3. Statements damaging a person's reputation or career.

4. Removing areas of responsibility, unjustifiably.

5. Not suitably giving insufficient or an excessive amount of work.

6. Constantly overruling authority without just cause.

7. Unjustifiably monitoring everything that is done.

8. Blaming a private perpetually for errors while not simply cause.

9. Repeatedly singling out an employee by assigning her with demeaning and belittling jobs that are not part of her regular duties.

10. Insults or humiliations, perennial tries to exclude or isolate an individual.

11. Consistently intrusive with traditional work conditions, sabotaging places or instruments of work.

12. Demeaning an individual ahead of colleagues, engaging in smear campaigns.

13. Arbitrarily taking disciplinary action against an employee.

14. Dominant the person by withholding resources (time, budget, autonomy, and training) necessary to succeed.

SOME SAMPLES SEXUAL HARASSMENT AT THE WORKPLACE BEHAVIOURS WHICH WILL NOT REPRESENT SEXUAL HARASSMENT:

1. Following-up on work absences.

2. Requiring performance to job standards.

3. The normal exercise of management rights.

4. Work-related stress e.g. meeting deadlines or quality standards.

5. Conditions of works.

6. Constructive feedback concerning the work mistake and not the person.

\section{FORMS OF WORKPLACE SEXUAL HARASSMENT:}

Generally sexual harassment at the workplace refers to 2 common varieties of inappropriate behaviour:

Quid Pro Quo (literally 'this for that')

- implicit or specific promise of preferential/detrimental treatment employed

- implicit or categorical threat concerning her gift or future employment standing

- Hostile Work Environment

- making a hostile, daunting or associate offensive work surroundings

- demeaning treatment seemingly to have an effect on her health or safety

\section{GENDER DIFFERENCE IN SEXUAL HARASSSMENT:}

When we think of sexual harassment, we may immediately think of male workers harassing or propositioning female coworkers. However, as many men can tell you, men can also face workplace sexually harassment. In fact, statistics indicate that almost or that nearly one in 5 complaints about sexual harassment at the workplace to the Equal Employment chance Commission (EEOC) came from men. The number of men coming forward is only increasing with movements such as \#TimesUp and \#MeToo, as the number of men reported harassment at work has increased from seven percent to 18 percent during the past year. ot all employers take the sexual harassment of men seriously, however, and harassment may continue long after a victim reports the is conduct. In addition, some male employees may experience retaliation for even complaining about harassment. Employees have the proper to freedom from sexism and harassment at work in spite of their genders.

Researchers have found that a minimum of one in six men have intimate regulatory offence or assault, whether in childhood or as adults. And this is often in all probability a coffee estimate, since it doesn't embrace noncontact experiences, which may even have lasting negative effects. Men and boys who have been sexually harassed may experience the same effects of sexual assault as other survivors, and they may face other challenges that are more unique to their experience. Some men United Nations agency have survived harassment as adults feel shame or timidness, basic cognitive process that they ought to are "strong enough" to oppose the offender. Many men United Nations agency intimate AN erection or ejaculation throughout the assault is also confused and surprise what this suggests. These normal physiological responses do not in any way imply that wanted, invited, or enjoyed the harassment. Men United Nations agency were sexually abused as boys or teens might also respond otherwise than men United Nations agency were sexually molested as adults.

\section{WHO ARE THE PERPETRATORS OF SEX OFFENSE AGAINST MEN?}

Perpetrators can be any gender identity, sexual orientation, or age, and they can have any relationship to the victim.

Like all perpetrators, they might use physical force or psychological and emotional coercion tactics.

\section{WHAT THE RESEARCH TELLS US:*}

A 2005 study conducted by the U.S. Centers for unwellness management, on San Diego Kaiser Permanente HMO members, reported that $16 \%$ of males were sexually abused by the age of 18.1

A 2003 national study of U.S. adults reportable that $14.2 \%$ of men were sexually abused before the age of 18.2 .

A 1998 study reviewing research on male childhood sexual abuse concluded that the problems is "common, underreported, under-recognized, and under-treated."

A 1996 study of male university students in the Boston area reported that $18 \%$ of men were sexually abused before the age of 16.4

A 1990 national study of U.S. adults reportable that 16 of men were sexually abused before the age of eighteen. 
WHY THESE STATTISTICS ARE PROBABLY UNDERE STIMATES

Males who have such experiences are less likely to disclose them than are females.

Only $16 \%$ of men with documented histories of sexual abuse (by social service agencies, which means it was very serious) considered themselves to have been sexually abused, compared to $64 \%$ of girls with documented histories within the same study.

MEN WHO'VE HAD SUCH EXPERIENCES ARE AT ABUNDANT LARGER RISK THAN PEOPLE WHO HAVEN'T FOR SERIOUS PSYCHOLOGICAL STATE ISSUES, INCLUDING:

- Symptoms of post-traumatic stress disorder and depression.

- Alcoholism and drug abuse.

- Suicidal thoughts and suicide attempts.

- Problems in intimate relationships.

- Underachievement at school and at work.

\section{RESEARCH METHODOLOGY:}

The method used in research study is exploratory type which involves descriptive and exploratory study. The research studied by using primary and secondary sources of information and data such as data collection through interview schedule, articles journals and books related to the Sexual Harassment in workplaces, which were analyzed and precisely to give a clear result and solutions for the research.

\section{STATEMENT OF THE PROBLEM:}

To study the sexual harassment at work place in Belagavi.

\section{OBJECTIVES:}

1. To understand the sexual harassment at work place. 2. To evaluate sexual harassment at work place at rural and urban area.

3. To Know the sexual harassment at work place among Male and female.

4. To analyze the sexual harassment at work place from different Professions.

\section{HYPOTHESIS:}

1. There would be a significant difference between male and female sexual Harassment.

2. There would be a significant difference in sexual harassment between different professional.

3. There would be significant difference between Rural and urban area in sexual harassment.

4. There would be significant correlation in sexual harassment between different professional.

\section{SAMPLE:}

Data for the present study was collected by self-report questionnaires. Respondents were sent a link to the anonymous survey via e-mail. Those who participated in the survey were working at different professions age from 19 to 29 years. Fifty of the respondents are male and seventy are female $(N=120)$. The sample who participated in this study was working in different professions in Belagavi district and from talukas of Belagavi. Samples were given one month to complete the questionnaire.

\section{DATA ANALYSIS :}

The data collected from primary and secondary sources were analysed by using both qualitative and quantitative methods depending on the nature of the data and were interpreted by employing appropriate statistical tools. The descriptive summary statistics such as simple mean, standard deviation, including frequencies and percentages were considered for the analysis of qualitative data. Computer softwares like
SPSS and Microsoft Excel were used to process the data.

\section{STATISTICAL TOOLS USED:}

For analyzing the data, simple classification and tabulation technique have been adopted. Wherever necessary, certain statistical techniques like averages and correlation have been used.

\section{RESULTS AND DISCUSSIONS}

Table 01 shows the parentage of yes and no of the Male sample response to sexual harassment at work place. $(\mathrm{N}=50)$

\begin{tabular}{|l|l|l|l|}
\hline $\begin{array}{l}\text { S. } \\
\text { No }\end{array}$ & Particulars & Yes & No \\
\hline 1 & $\begin{array}{l}\text { You have supervisors or colleagues that you } \\
\text { want to avoid working together. }\end{array}$ & $69 \%$ & $31 \%$ \\
\hline 2 & $\begin{array}{l}\text { You feel that somebody is constantly staring } \\
\text { at you. }\end{array}$ & $02 \%$ & $98 \%$ \\
\hline 3 & $\begin{array}{l}\text { The number of female and male workers is } \\
\text { not well-balanced. }\end{array}$ & $45 \%$ & $55 \%$ \\
\hline 4 & $\begin{array}{l}\text { There are times when supervisors or } \\
\text { colleagues touch your body. }\end{array}$ & $55 \%$ & $45 \%$ \\
\hline 5 & $\begin{array}{l}\text { There are uncomfortable incidences at my } \\
\text { workplace but I tolerate it with my patience. }\end{array}$ & $03 \%$ & $97 \%$ \\
\hline 6 & $\begin{array}{l}\text { My supervisor sometimes asks me out for } \\
\text { dinner. }\end{array}$ & $59 \%$ & $41 \%$ \\
\hline 7 & $\begin{array}{l}\text { I stay obedient to whatever my supervisor } \\
\text { says as I do not want to lose my job. }\end{array}$ & $79 \%$ & $21 \%$ \\
\hline 8 & $\begin{array}{l}\text { I receive some jokes and comments related } \\
\text { to my appearance. }\end{array}$ & $83 \%$ & $17 \%$ \\
\hline 9 & $\begin{array}{l}\text { My supervisor frequently asks me about my } \\
\text { personal life. }\end{array}$ & $71 \%$ & $29 \%$ \\
\hline 10 & $\begin{array}{l}\text { I often receive emails irrelevant to my work } \\
\text { from a colleague/supervisor. }\end{array}$ & $63 \%$ & $37 \%$ \\
\hline
\end{tabular}

Table no 01 shows the percentage of male respondents sexual harassment, the sample were asked total 10 questions. $69 \%$ of men avoid working with some colleagues, $55 \%$ men reported that sometimes their supervisors or colleagues touch their body. $79 \%$ male work because to not to lose job they suffer some or the other type of harassment to protect their job. $71 \%$ men reported that their boss ask the personal life. Some respondents also added that they ask about the sexual life details. $83 \%$ respondents admitted that they got jokes and comments related to appearance. All the above percentage related to male repots shows that men are also face the sexual harassment at work place.

Table 02 shows the parentage of yes and no of the Female sample response to sexual harassment at work place. $(\mathrm{N}=70)$

\begin{tabular}{|l|l|l|l|}
\hline $\begin{array}{l}\text { S. } \\
\text { No }\end{array}$ & Particulars & Yes & No \\
\hline 1 & $\begin{array}{l}\text { You have supervisors or colleagues that you } \\
\text { want to avoid working together. }\end{array}$ & $89 \%$ & $11 \%$ \\
\hline 2 & $\begin{array}{l}\text { You feel that somebody is constantly staring } \\
\text { at you. }\end{array}$ & $61 \%$ & $39 \%$ \\
\hline 3 & $\begin{array}{l}\text { The number of female and male workers is } \\
\text { not well-balanced. }\end{array}$ & $56 \%$ & $44 \%$ \\
\hline 4 & $\begin{array}{l}\text { There are times when supervisors or } \\
\text { colleagues touch your body. }\end{array}$ & $72 \%$ & $28 \%$ \\
\hline 5 & $\begin{array}{l}\text { There are uncomfortable incidences at my } \\
\text { workplace but I tolerate it with my patience. }\end{array}$ & $82 \%$ & $18 \%$ \\
\hline 6 & $\begin{array}{l}\text { My supervisor sometimes asks me out for } \\
\text { dinner. }\end{array}$ & $34 \%$ & $66 \%$ \\
\hline 7 & $\begin{array}{l}\text { I stay obedient to whatever my supervisor } \\
\text { says as I do not want to lose my job. }\end{array}$ & $61 \%$ & $39 \%$ \\
\hline 8 & $\begin{array}{l}\text { I receive some jokes and comments related to } \\
\text { my appearance. }\end{array}$ & $08 \%$ \\
\hline
\end{tabular}


\begin{tabular}{|l|l|l|l|}
9 & My supervisor frequently asks me about my & $90 \%$ & $10 \%$
\end{tabular} personal life.

10 I often receive emails irrelevant to my work from a colleague/supervisor.

Table no 02 shows the percentage of respondents sexual harassment of female respondents, the sample were asked same total 10 questions which are asked to men. Female respondents remarked that $89 \%$ will want avoid working to avoid with some colleague. $92 \%$ sample received some jokes and comments related to their physical appearance. $90 \%$ female boss asked to her personal life details. $87 \%$ respondents received emails irrelevant to work from a colleague/supervisor.(respondents added that they received not only emails they also received whatsapp and face book messages which is not related to work.) $61 \%$ women stay obedient to whatever supervisor says as they do not want to lose their job.72\% female reported that supervisors or colleagues touch the body unnecessarily. $61 \%$ feel that somebody is constantly staring at them. This persentage report received by female clearly give the evidence for sexual harassment at work place.

Table 03 shows the mean, sd and t-values of response to sexual harassment at work place. $(\mathrm{N}=70)$

\begin{tabular}{|c|c|c|c|c|}
\hline \multicolumn{2}{|c|}{ Indicators } & Mean & Std. Deviation & t-value \\
\hline \multirow{2}{*}{ Area } & Urban & 2.27 & 1.531 & $2.965^{*}$ \\
\cline { 2 - 4 } & rural & 1.70 & 1.412 & \\
\hline \multirow{2}{*}{ Gender } & Female & 2.24 & 1.490 & \multirow{2}{*}{$3.895^{*}$} \\
\cline { 2 - 4 } & Male & 1.43 & 1.466 & \\
\hline
\end{tabular}

*Significant at 0.01 Level **0.05 Level @ not significant

Above table shows the mean, sd, and $t$ value of sexual harassment at work place. The mean and sd of urban sample is higher i.e 2.27, and 1.531 than rural sample i.e. 1.70 and 1.412. The calculated t-value is 2.965 which is significant at 0.01 level of significance. Hence the scores indicate that urban respondents have more sexual harassment than rural respondents at work place.

The mean, sd, and t value of male and female towards sexual harassment. The mean and sd of female is higher i.e 2.24, and 1.490 than male i.e 1.43 and 1.466. The calculated t-value is 3.895 which is significant. Hence the scores indicate that comparing to men female have more sexual harassment at work place.

Table 04 shows the mean, sd and t-values of different professionals to sexual harassment at work place. $(N=70)$

\begin{tabular}{|l|l|l|l|l|}
\hline \multicolumn{2}{|l|}{ Indicators } & Mean & Std. Deviation & t-value \\
\hline Police & Male & 2.31 & 1.246 & $-2.269^{* *}$ \\
\cline { 2 - 4 } & Female & 2.67 & 1.175 & \\
\hline \multirow{2}{*}{ Teacher } & Female & 2.92 & 1.230 & $2.084^{* *}$ \\
\cline { 2 - 4 } & Male & 2.40 & 1.249 & \\
\hline \multirow{2}{*}{ Doctors } & Female & 2.44 & 1.271 & $0.424 @$ \\
\cline { 2 - 4 } & Male & 2.37 & 1.149 & \\
\hline
\end{tabular}

*Significant at 0.01 Level **0.05 Level @ not significant

Above table 4 shows the mean, sd, and t value of different professions sexual harassment at work place. The mean and sd of female police is higher i.e 2.67, and 1.175 than male police i.e. 2.31 and 1.246. The calculated t-value is -2.269 which is significant at 0.05 level of significance. Hence the scores indicate that female police opines more than male police.

The mean and sd of female teacher is higher that is 2.92 and 1.230 than male teacher i.e. 2.40 and 1.249. The calculated tvalue is 2.084 which is significant at 0.05 level of significance.
Hence it proves that female teacher receives more sexual harassment at work place than male teacher.

The mean and sd of female doctor is higher i.e 2.44 and 1.271 than male doctor i.e 2.37 and 1.149. The calculated t-value is .424 which is not significant. Hence there is no significant difference between male and female doctor

Table 05 shows the correlation coefficient of different professionals to sexual harassment at work place. $(\mathrm{N}=70)$

\begin{tabular}{|l|l|l|l|}
\hline Variables & Teachers & Police & Doctors \\
\hline Teachers & 00 & $0.37 @$ & $0.42 @$ \\
\hline Police & $0.37 @$ & 00 & $0.25 @$ \\
\hline Doctors & $0.42 @$ & $0.25 @$ & 00 \\
\hline
\end{tabular}

* Significant at 0.01 Level **0.05 Level @ not significant

When spearman Brown formula was applied to find the correlation between different professions sexual harassment at work place but all the values found to be not significant.

\section{CONCLUSION:}

Sexual harassment can happen to anyone, no matter of age, sexual orientation, or gender identity. Men and boys who have been sexually assaulted or abused may have many of the same feelings and reactions as other survivors of sexual assault, but they may also face some additional challenges because of social attitudes and stereotypes about men and masculinity. In conclusion, the 1 in 6 men and 2 in 5 female statistic is supported by solid scientific research, including a study conducted by the U.S. Centers, and is likely an underestimate of the actual prevalence. Furthermore, the present research also provides the evidence for it. This widespread problem contributes to mental health, personal and work difficulties of many women as well as women. Yet few people are aware that there are just as many men who experienced sexual abuse as children as there is who develop many problems.Besides improving on the then existing procedure, the guideline also speeded up the process of taking disciplinary action against public servants committing such activities against men Howe ever women have the guidelines.

\section{ANNEXURE:}

\section{QUESTIONNAIRE :}

1. You have supervisors or colleagues that you want to avoid working together. YES/NO

2. You feel that somebody is constantly staring at you. YES/NO

3. The number of female and male workers is not wellbalanced. YES/NO

4. There are times when supervisors or colleagues touch your body. YES/NO

5. There are uncomfortable incidences at my workplace but I tolerate it with my patience. YES/NO

6. My supervisor sometimes asks me out for dinner. YES/NO

7. I stay obedient to whatever my supervisor says as I do not want to lose my job. YES/NO

8. I receive some jokes and comments related to my appearance. YES/NO

9. My supervisor frequently asks me about my personal life. YES/NO

10. I often receive emails irrelevant to my work from a colleague/supervisor. YES/NO

\section{REFERENCES:}

1. Dube, S.R., Anda, R.F., Whitfield, C.L., et al. (2005). Long-term consequences of childhood sexual abuse by gender of victim. American Journal of Preventive Medicine, 28, 430-438.

2. Briere, J. \& Elliot, D.M. (2003). Prevalence and psychological sequelae of selfreported childhood physical and sexual abuse in a general population sample of men and women. Child Abuse \& Neglect, 27, 1205-1222.

3. Holmes, W.C., \& Slap, G.B. (1998). Sexual abuse of boys: Definition, 
prevalence, correlates, sequelae, and management. Journal of the American Medical Association (JAMA), 280, 1855-1862.

4. Lisak, D., Hopper, J. \& Song, P. (1996). Factors in the cycle of violence: Gender rigidity and emotional constriction. Journal of Traumatic Stress, 9, 721-743.

5. Finkelhor, D., Hotaling, G., Lewis, I. A., \& Smith, C. (1990). Sexual abuse in a national survey of adult men and women: Prevalence, characteristics, and risk factors. Child Abuse \& Neglect, 14, 19-28.

6. Holmes, G R Offen L \& Waller, G (1997). See no evil, hear no evil, speak no evil: Why do relatively few male victims of childhood sexual abuse receive help for abuse-related issues in adulthood? Clinical Psychology Review, 17, 69-88.

7. Widom, C.S. \& Morris, S. (1997). Accuracy of adult recollections of childhood victimization part 2. Childhood sexual abuse. Psychological Assessment, 9, $34-46$.

8. Widom (1999). Posttraumatic stress disorder in abused and neglected children grown up. American Journal of Psychiatry, 156, 1223-1229.

9. Felitti, V.J., Anda, R.F., Nordenberg, D., Williamson, D.F., Spitz, A.M., et al. (1998). Relationship of childhood abuse and household dysfunction to many of the leading causes of death in adults. American Journal of Preventive Medicine, 14, 245-258.

10. Lisak, D. \& Luster, L. (1994). Educational, occupational and relationship histories of men who were sexually and/or physically abused as children. Journal of Traumatic Stress, 7, 507-523.

11. Patel, V. (2005), A brief history of battle against sexual harassment at workplace, InfoChange News and Features. Accessed on 10th May 2013, Can be retrieved from http://infochangeindia.org/women/analysis/a-briefhistoryof-the-battle-against-sexual-harassment-atthe- workplace.html Agarwal, A. (1992). Sexual Harassment: A Guide for Understanding and Prevention, Butterworths, Toronto.

12. Deshpande, V. (2012). Sealed lips, flawed attitudes worsen plight of working women, The Hindu. Accessed on lst January 2013.

13. Bhattacharyya, Arundhati. Sexual Harassment in the Indian Bureaucracy: Violation of Human Rights. Cambridge Scholars Publishing, 2017.

14. Bothra, Nidhi. "The Sexual Harassment of Women at Workplace (Prevention, Prohibition and Redressal) Act, 2013." SSRN Electronic Journal, 2014, doi:10.2139/ssrn.24989 